\title{
フッ素樹脂コーティングガラスと医薬品の相互作用の検討
}

\author{
河野弥生, ${ }^{a}$ 大津早紀, ${ }^{a}$ 馬場孝夫, ${ }^{b}$ 花輪剛久 $*, a$
}

\section{Study of Interaction between Fluorinated Coating Glass and the Medicines}

\author{
Yayoi Kawano, ${ }^{a}$ Saki Otsu, ${ }^{a}$ Takao Bamba, ${ }^{b}$ and Takehisa Hanawa*,a \\ ${ }^{a}$ Faculty of Pharmaceutical Sciences, Tokyo University of Science; 2641 Yamazaki, Noda, Chiba 278-8510, Japan: \\ and ${ }^{b}$ Namicos Corporation; Ohtemaye 2-3-14, Uchihiranomachi, Chuo-ku, Osaka 540-0037, Japan.
}

(Received April 18, 2017; Accepted July 18, 2017; Advance publication released online July 25, 2017)

\begin{abstract}
The adsorption of active pharmaceutical ingredients on the surface of medical devices such as polyvinl chloride, ethylene-vinyl acetate copolymer and glass often prevent the acuurate dose of drug. At dispensing of pharmaceuticals, mètre glass (MG) has been widely used for dispensing syrup. When measuring the viscous syrup, it often takes long time to dispense the accurate volume due to their adhesiveness on the glass surface. In this study, we investigate the adhesion of various syrups to MG made with uncoated glass or glass with a strongly hydrophobic silicone or fluorinated coating in terms of the following formulation parameters: viscosity, surface tension, contact angle, and surface free energy. The contact angles for syrups on the coated glass surfaces were significantly higher than those on the uncoated glass surface. In addition, the relationship between surface tension and contact angle was examined. We found that the contact angle was independent of surface tension for the uncoated glass, while it increased with increasing surface tension for the coated glasses. These results can be explained as follows: the silicone or fluorinated coatings inhibit the hydrogen bonding that usually takes place between water and silanol and siloxane groups at glass surfaces. The coatings reduced the surface free energy and increased the hydrophobicity of the glass, reduced its wettability by the syrups, and thus reduced the adhesion loss for the syrups. It was considered that as for the hydrophobic action, properties of matter of sample influence the coated device by coating in order that it is reinforced.
\end{abstract}

Key words__ interaction; glass; fluorinated coating; surface free energy; syrup

\section{緒言}

医薬品包装及び容器は使用直前まで医薬品の品質 を確保する上で重要な役割を担つている。医薬品包 装や医療用具には様々な素材が使用されているが, 医薬品, 医薬品添加物と素材間の相互作用による主 薬の分解, 含有量低下に関する報告は多く, 特にガ ラス製容器，医薬品包装や医療用具に用いられてい るポリ塩化ビニル，エチレンビニル共重合体等の医 療用高分子に対する医薬品の吸着や収着による投与 量の低下は，医薬品の適正使用の妨げとなってい る. ${ }^{1-5)}$

近年, 微量で高い活性を示す多種多様なタンパク 製剂が開発されているが，これら医薬品を充填する ガラス製バイアル表面への吸着による投与量の低減

$a$ 東京理科大学薬学部, $b$ 株式会社ナミコス

*e-mail: t-hanawa@rs.tus.ac.jp

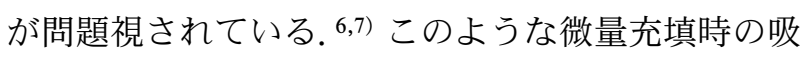
着防止を目的としてガラス表面をシリコーン樹脂 コーティングし，撥水性及び撥粉性を向上した医薬 品バイアルが市販されている. ${ }^{8,9)}$ シリコーン樹脂加 工はガラス製容器をジメチルポリシロキサン溶液に 浸漬後, 焼き付け処理を行うことによりガラス表面 にシリコーン樹脂の薄膜を形成させて撥水性を高 め, ガラス内表面への薬液の残留を防ぐことを目的 としている.

一方，近年，さらに撥水性の向上を目的として, フッ素樹脂コーティングを施したガラスバイアルが 着目されている．フッ素樹脂加工はカップリング剂 を用いてフッ素樹脂を塗布後, 焼き付け処理を行 い, 内表面にフッ素樹脂の薄膜を形成させる方法で あり, 撥水性を高め, ガラス内表面への薬液の残留 を防ぐことができる．また，薬液がガラス内表面に 直接接触しなくなるため, ガラス成分の溶出を抑制 し，かつ，フレークスの発生の抑制が期待できると 
されている. ${ }^{10)}$

これらのコーティング処理を施したガラス表面と 医薬品との相互作用を検討した事例として，山本ら はガラス製メートグラスに対するシロップ剂の付着 に着目し，調剂時にシリコーン樹脂コーティング処 理ガラスや表面自由エネルギーの低い高分子を素材 としたメートグラスを用いると，シロップ剤のメー トグラス表面への付着による損失が低減すると報告 している. ${ }^{11,12)}$

しかし，フッ素樹脂コーティングによる表面改質 技術をガラス製デバイスに応用した事例はなく，医 薬品との相互作用を検討した事例もない.

そこで本研究ではガラス製デバイスとして， シ ロップ剂などの液剂の秤取に使用されるメートグラ スをモデルデバイスとし，表面をシリコーン樹脂 コーティング，フッ素樹脂コーティングしたメート グラスを新たに作製し，シロップ剂及び液剤の物性 の違いが医薬品のガラス表面への付着に及ぼす影響 について検討するとともに，フッ素樹脂コーティン グ処理ガラスの医療器具への応用の可能性について 検討した.

\section{方法}

1. 試料アスベリンシロップ $0.5 \%$ （田辺三 菱製薬株式会社，大阪），ポンタールツシロップ $3.25 \%$ (第一三共株式会社, 東京), ペリアクチン シロップ 0.04\%（日医工株式会社，富山），ムコダ インシロップ 5\%（杏林製薬株式会社，東京）, ファンギゾン®シロップ $100 \mathrm{mg} / \mathrm{mL}$ （ブリストル・ マイヤーズ スクイブ株式会社，東京），日本薬局方 単シロップ（丸石製薬株式会社，大阪）をそれぞれ 購入した。また，エタノール及びオレイン酸はそれ ぞれ関東化学株式会社（東京），ナカライテスク株 式会社（京都）より購入した。種々のポリオキシエ チレンラウリルエーテル（POE）（NIKKOL $\mathrm{BL}-4.2 ，-9 \mathrm{EX}$ 及び-21）は，日光ケミカルズ株式会 社（東京）より入手した.

なお，試薬はすべて特級品を使用した。

\section{2. 種々の HLB 值を示す界面活性剂水溶液の調} 製 NIKKOL BL-4.2，-9EX 及び-21をそれぞれ 精製水に溶解し， hydrophilic-lipophilic balance (HLB) 值 $11.5 ， 14.5$ 及び 19.0 の 1\%（w/v） POE 水溶液を調製した.
3. コーティングガラスの作製ホウケイ酸ガ

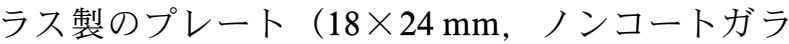
ス： $\mathrm{NCG)} \mathrm{又はメートグラス}(20 \mathrm{~mL}$ ，株式会社 三商，東京，ノンコートメートグラス： $\mathrm{NCMG)}$ の表面にシリコーン樹脂コーティング及びフッ素樹 脂コーティングを施した.

シリコーン樹脂コーティングは， $1 \%$ ジメチルポ リシロキサン溶液（KM-740K，信越化学工業株式 会社，東京）をガラス表面に塗布し，焼成炉中で焼 き付けた.

一方，フッ素樹脂コーティングは，カップリング 剤である $0.15 \%$ 3-アミノプロピルトリメトキシシ ラン（KBE-903，信越化学工業株式会社，東京）を ガラス表面に塗布・焼き付けし, 冷却後, バートレ ルTM スープリオンTM (三井・デュポンフロロケミ カル株式会社，東京）で $1 \%$ に希釈したテフロンTM AF1600 (三井・デュポンフロロケミカル株式会社, 東京）溶液を塗布し，焼成炉中で焼き付けた。

本実験系ではコーティングを施したガラスプレー ト及びメートグラスをそれぞれ，シリコーン樹脂 コートガラス（SiCG)，シリコーン樹脂コートメー トグラス（SiCMG)，フッ素樹脂コートガラス （FCG）及びフッ素樹脂コートメートグラス (FCMG) とした。

4. 試料の粘度の測定 $25^{\circ} \mathrm{C}$ における各試料 の粘度は，回転粘度計（東機産業株式会社，東京， $\mathrm{E}$ 型粘度計 VISCOMETER，ロータ : $\left.1^{\circ} 34^{\prime} \times \mathrm{R} 24\right)$ を用いて測定した。

5. 表面張力 · 接触角の測定 各試料の表面張 力 $\left(20 \pm 0.5^{\circ} \mathrm{C}\right)$ を, 表面張力計（協和界面科学株 式会社，新座，FACE CBVP-A3 型）を用いて Wilhelmy 法（プレート法）により測定した.

室温 $\left(20 \pm 0.5^{\circ} \mathrm{C}\right)$ において，ガラスプレートの 表面上に精製水，ジヨードメタン， $n$-ヘキサデカン をそれぞれ滴下し，液滴の接触角を接触角計（協和 界面科学株式会社, 新座, FACE 接触角計 CAX150 型）を用いて測定した。さらに，NCG， $\mathrm{SiCG}$ 及び FCG に各試料を滴下し，各試料の接触 角を測定した。

6. 表面自由エネルギーの算出接触角より, 下記の北崎・畑の式 Eqs.（1），(2)を用いて各ガラ スの表面自由エネルギーを算出した. ${ }^{13)}$ プローブ溶 液は，精製水，ジヨードメタン， $n$-ヘキサデカンを 
使用した。

$$
\begin{aligned}
r_{\text {total }}=r^{d}+r^{p}+r^{h} & \\
r_{L}^{\text {total }}(1+\cos \theta)= & 2\left(r_{S}^{d} \cdot r_{L}^{d}\right)^{0.5}+2\left(r_{S}^{p} \cdot r_{L}^{p}\right)^{0.5} \\
& +\left(r_{S}^{h} \cdot r_{L}^{h}\right)^{0.5}
\end{aligned}
$$

$\theta:$ 接触角, $r_{S}$ : 固体の表面自由エネルギー, $r_{L}:$ 液体の表面自由エネルギー, $d:$ 分散成

分, $p:$ 極性成分, $h:$ 水素結合成分

なお, 各プローブの表面張力成分は精製水 $\left(r^{d}=\right.$ $\left.29.1, r^{p}=1.3, r^{h}=42.4\right), \quad$ ジョードメタン $\left(r^{d}=\right.$ $\left.46.8, r^{p}=4.0, r^{h}=0.0\right), n$-ヘキサデカン $\left(r^{d}=27.6\right.$, $\left.r^{p}=0.0, r^{h}=0.0\right)$ を使用した.

7. メートグラスへの医薬品付着残存率の測定 山本らの方法を参考にした. ${ }^{12)}$ 空のメートグラス の質量を測定後，メートグラスに試料 $10 \mathrm{~mL}$ を量 り取り，その質量を測定した。次に，メートグラス 下部を中心とし，時計回り方向に回転速度 $5 \mathrm{rpm}$ でメートグラスを傾倒し, 受容器上部の水平面と メートグラス壁面の角度を $45^{\circ}$ で接触後, 15 秒間停 止し，受容器に試料を流下させた（Fig. 1)。その 後, メートグラスの質量を測定し, 下記の式 Eq. （3）を用いてメートグラス内の残存率を算出した.

$$
\mathrm{R}(\%)=\left(\mathrm{W}_{\mathrm{after}}-\mathrm{W}\right) /\left(\mathrm{W}_{\text {total }}-\mathrm{W}\right) \times 100
$$

$\mathrm{R}$ : 残存率 $(\%), \mathrm{W}$ ：メートグラスの質量 $(\mathrm{g}), \mathrm{W}_{\text {total }}$ : 試料 $10 \mathrm{~mL}$ を含むメートグラ スの質量 $(\mathrm{g}), \mathrm{W}_{\mathrm{aftert}}$ : 試料流下後のメート グラスの重量 $(\mathrm{g})$

\section{結果及び考察}

1. 試料の粘度 各試料の流動曲線を Fig. 2 に 示す.また, $25^{\circ} \mathrm{C}$, 回転数 $50 \mathrm{rpm}$ で測定した際の 粘度を Table 1 に示す。ペリアクチンシロップ, ム コダイン®シロップの粘度は低く, アスベリン®シ

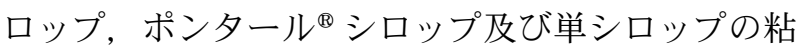
度は高值を示したが，いずれの試料も流動曲線では ニュートン流動に特徵的なレオグラムを示した。こ れに対し，ファンギゾンシシロップの粘度は最も高 值を示し，流動曲線においても非ニュートン流動を 示した (Fig. 2).

\section{2. 表面張力・接触角及び表面自由エネルギー}

Table 1 に各試料の表面張力, Table 2 に各試料 の添加剂を示す。本実験で観察された精製水の表面 張力は $72.7 \mathrm{dyne} / \mathrm{cm}$ であったのに対し，界面活性 作用を示さないショ糖を $85 \%(\mathrm{w} / \mathrm{v})$ 含有する単シ

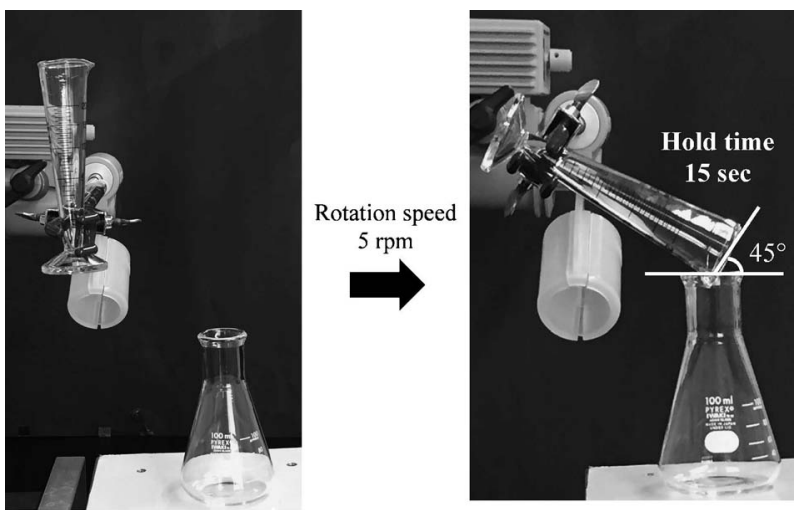

Fig. 1. The Picture of the Measurement Apparatus

ロップの表面張力は負吸着により $77.9 \mathrm{dyne} / \mathrm{cm}$ と 大きな值を示した. ムコダインシロップの表面張力 が $71.1 \mathrm{dyne} / \mathrm{cm}$ と精製水とほぼ同様の值を示した 理由については本研究では明らかにすることができ なかったが，主薬であるカルボシステインは極めて 水に溶け難いため, $\mathrm{pH}$ 調整剂を添加して可溶化し ている，そのため，成分中に糖アルコールを含有す るものの, 添加されている緩衝剂に含まれる塩など の存在により表面張力の低下が抑えられたと推察さ れる. 一方, 糖アルコールやエタノールを始め, 種 々の添加剤を含有するシロップ剂では正吸着により 表面張力が減少する傾向が認められた.

これらのシロップ剂を NCG， SiCG 及び FCG 製 プレパラート上に滴下して接触角を観察したとこ ろ，いずれの試料においても $\mathrm{NCG}<\mathrm{SiCG}<\mathrm{FCG}$ の順に接触角は大きくなったことから（Table 3), ガラス表面をシリコン又はフッ素樹脂コーティング することにより撥水効果が顕著に現れていることを 示している.

Figure 3 に各試料の表面張力と接触角の関係を示 す. NCMG は表面張力が増加しても接触角の変化 はほとんど認められなかったが，SiCMG 及び FCMG では表面張力が大きいほど接触角の増加が 認められた（Fig. 3)。空ガラス等に用いられる一 般的なガラスは $\mathrm{Na}_{2} \mathrm{O}-\mathrm{CaO}-\mathrm{SiO}_{2}$ を基本組成として いるが, 本実験系で用いた NCG は医療用ガラス器 具に汎用されているホウケイ酸ガラスで $\mathrm{Na}_{2} \mathrm{O}-\mathrm{B}_{2} \mathrm{O}_{3}-\mathrm{SiO}_{2}$ の基本組成のほか, $\mathrm{Al}_{2} \mathrm{O}_{3}, \mathrm{CaO}$, $\mathrm{BaO}, \mathrm{K}_{2} \mathrm{O}$ なども含有しており, シロップ剂中の成 分と水素結合, van der Waals 力などにより分子間 相互作用していると推察される。一方, SiCMG 及 


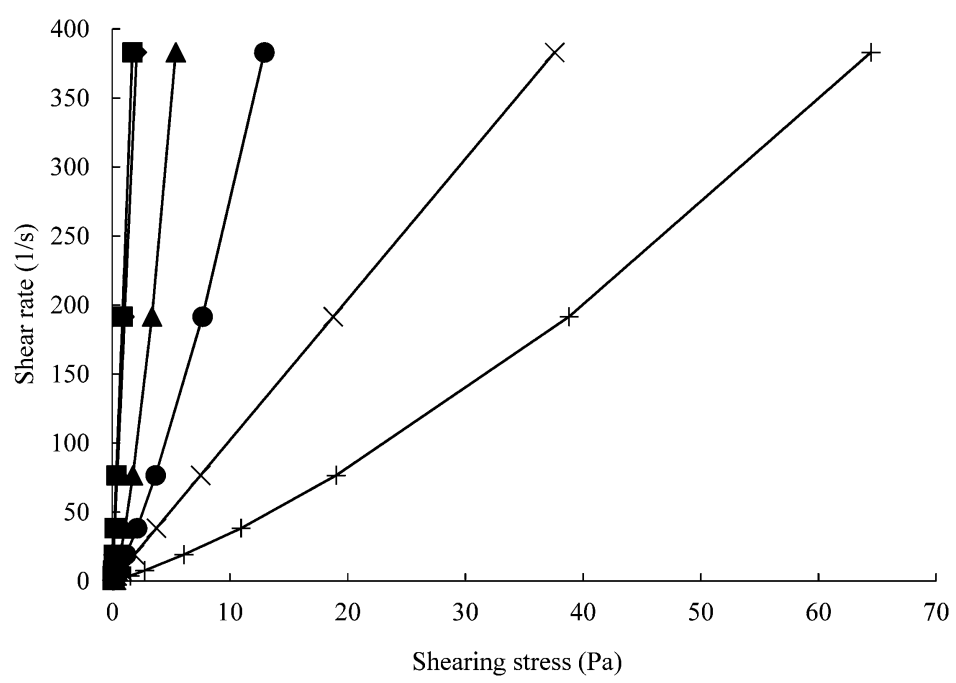

Fig. 2. Rheogram of the Various Sample Solutions

口, Periactin syrup, $\bullet$, Mucodyne ${ }^{\circledR}$ syrup, $\boldsymbol{\Delta}$, Asverin ${ }^{\circledR}$ syrup,

, Pontal ${ }^{\circledR}$ syrup, $\times$, Simple syrup,,+ Fungizone $^{\circledR}$ syrup.

Table 1. Surface Tension and Viscosity of Various Sample Solutions

\begin{tabular}{lcc}
\hline \hline Sample & $\begin{array}{c}\text { Surface tension } \\
(\text { dyne } / \mathrm{cm})^{\mathrm{a}}\end{array}$ & $\begin{array}{c}\text { Viscosity } \\
(\mathrm{mPa} \cdot \mathrm{s})^{\mathrm{b}}\end{array}$ \\
\hline Periactin syrup $^{\mathrm{c}}$ & 39.1 & 5.5 \\
Mucodyne $^{\circledR}$ syrup & 71.1 & 4.5 \\
Asverin $^{\circledR}$ syrup & 28.9 & 17.7 \\
Pontal $^{\circledR}$ syrup & 57.3 & 40.4 \\
Fungizone $^{\circledR}$ syrup & 42.4 & 203.6 \\
Simple syrup $_{\text {Purified water }}$ & 77.9 & 97.9 \\
\hline
\end{tabular}

${ }^{\text {a }}$ Measured at $20 \pm 0.5^{\circ} \mathrm{C},{ }^{\text {b }}$ Measured at $50 \mathrm{rpm}, 25^{\circ} \mathrm{C}$.

び FCMG では，それぞれのコーティング皮膜とし て従来撥水作用を有する成分で被覆されているた め，シロップ剂中の成分と相互作用し難い状態にあ ると考えられる.

3. メートグラス中の試料の観察及び実験に伴う コーティング状態の変化Ｆigure 4 に精製水を 1 , $5,10 \mathrm{~mL}$ ずつ別途シリンジにて採取し，各種メー トグラスに滴下した際のメニスカス部分の様子を示 す。NCMG のメニスカス部分は凹形を示したのに 対し，SiCMG 及び FCMG では，上に凸形の様相 を呈し，しかも，標線から曲面の最高点までの高さ はSiMGよりも FCMGの方が高く観察された.

本実験系では水溶液を試料として用いたため，秤 取すべき量は SiCMG 及び FCMG の目盛を読み取 るときにはメニスカス部分の両端を使用するが，水 銀のように上に凸形のメニスカス部分の中央を読み 取る場合もあり，量り取る試料一壁面間の界面張力
Table 2. Liquid Samples and Their Ingredients

\begin{tabular}{|c|c|c|}
\hline Liquids samples & API & Additives \\
\hline Periactin syrup & $\begin{array}{l}\text { Cyproheptadine } \\
\text { hydrochloride } \\
\text { hydrate }\end{array}$ & $\begin{array}{l}\text { sucrose, saccharin sodium, } \\
\text { glycerol, ethanol, sorbic } \\
\text { acid, sodium hydroxide, } \\
\text { flavor ingredient }\end{array}$ \\
\hline $\begin{array}{l}\text { Mucodyne }^{\circledR} \\
\text { syrup }\end{array}$ & L-carbocisteine & $\begin{array}{l}\text { D-sorbitol, sorbic acid, } \\
\text { caramel, flavor ingredient, } \\
\text { pH regulator }\end{array}$ \\
\hline Asverin ${ }^{\circledR}$ syrup & $\begin{array}{l}\text { Tipepidine } \\
\text { hibenzate }\end{array}$ & $\begin{array}{l}\text { sodium benzoate, citric } \\
\text { acid, sodium citrate, } \\
\text { glycerol ester of fatty acid, } \\
\text { sodium saccharin, sucrose } \\
\text { fatty acid ester, silicone } \\
\text { resin, D-sorbitol, ethanol, } \\
\text { etc. }\end{array}$ \\
\hline Pontal $^{\circledR}$ Syrup & Mefenamic acid & $\begin{array}{l}\text { polyvinylpyrrolidone, alu- } \\
\text { minum magnesium sili- } \\
\text { cate, sodium carmellose, } \\
\text { sodium benzoate, D-sor- } \\
\text { bitol, sucrose }\end{array}$ \\
\hline $\begin{array}{l}\text { Fungizone }{ }^{\circledR} \\
\text { syrup }\end{array}$ & Amphotericin B & $\begin{array}{l}\text { methyl parahydroxyben- } \\
\text { zoate, propyl } p \text {-hydroxy- } \\
\text { benzoate, D-sorbitol, } \\
\text { sodium benzoate, potassi- } \\
\text { um chloride, ethanol, } \\
\text { glycerol, sodium carmel- } \\
\text { lose, anhydrous citric acid, } \\
\text { yellow No. } 5 \text { aluminium } \\
\text { lake, red No. } 3 \text { aluminium } \\
\text { lake, etc. }\end{array}$ \\
\hline Simple syrup & sucrose & - \\
\hline Purified water & - & - \\
\hline
\end{tabular}

も考慮した標線の設定が必要となるため, 今後解決 すべき課題であると考える.

また，本実験においてコーティング表面の破損や 劣化は目視では認められなかった。本コーティング 
Table 3. Contact Angle of Various Sample Solutions

\begin{tabular}{|c|c|c|c|}
\hline & $\mathrm{NCG}\left({ }^{\circ}\right)^{\mathrm{a}}$ & $\operatorname{SiCG}\left({ }^{\circ}\right)^{a}$ & $\mathrm{FCG}\left({ }^{\circ}\right)^{\mathrm{a}}$ \\
\hline Periactin syrup & 19.8 & 95.6 & 106.2 \\
\hline Mucodyne ${ }^{\circledR}$ syrup & 19.2 & 106.7 & 112.6 \\
\hline Asverin ${ }^{\circledR}$ syrup & 25.9 & 78.3 & 90.9 \\
\hline Pontal $^{\circledR}$ syrup & 20.9 & 105.4 & 108.5 \\
\hline Fungizone ${ }^{\circledR}$ syrup & 30.7 & 104.6 & 118.2 \\
\hline Simple syrup & 28.5 & 91.8 & 102.7 \\
\hline Purified water & 5.0 & 106.4 & 121.1 \\
\hline
\end{tabular}

${ }^{\text {a }}$ Measured at $20 \pm 0.5^{\circ} \mathrm{C}$.

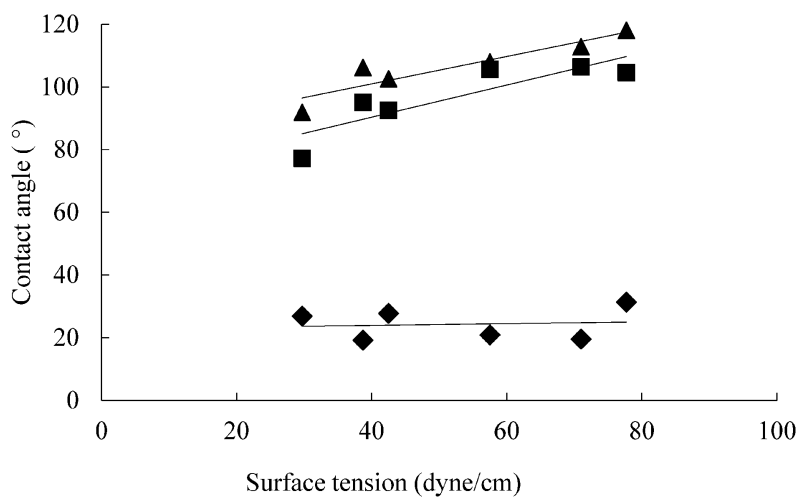

Fig. 3. Relationship between Contact Angle and Surface Tension of Various Sample Solutions

$\diamond$, NCMG, $\mathbf{\square}$, SiCMG, $\boldsymbol{\Delta}$, FCMG.

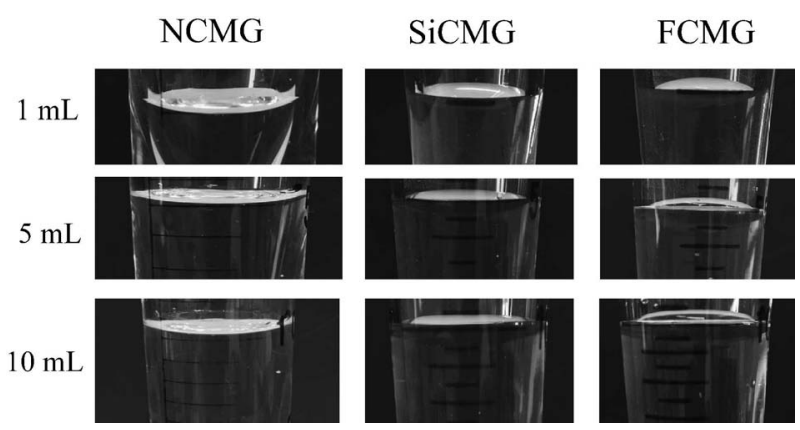

Fig. 4. The Meniscus of Metering Glasses

技術は医薬品用のガラスバイアルに応用されている ことから，医薬品によるコーティングへの影響は考 え難い.しかし，メートグラスのように繰り返し洗 浄して使用する器具の場合は，耐久性などを検討す る必要がある.

4. NCG, SiCG, FCG の表面自由エネルギー 北崎・烟らは，表面張力を分散成分，双極子成 分，水素結合成分の 3 種の異なる成分の和として表 現できるとし，分散成分は「すべての分子が常に振 動することにより生じる電荷の隔たりにより発生す
Table 4. Contact Angle of Variance Component and Polar Component in Each Glass

\begin{tabular}{lccc}
\hline \hline & \multicolumn{3}{c}{ Contact angle $\left(^{\circ}\right)$} \\
\cline { 2 - 4 } & Purified water & Diiodomethane & $n$-Hexadecane \\
\hline NCG & 5.5 & 30.5 & 19.7 \\
SiCG & 106.8 & 62.8 & 16.8 \\
FCG & 118.2 & 91.6 & 68.1 \\
\hline
\end{tabular}

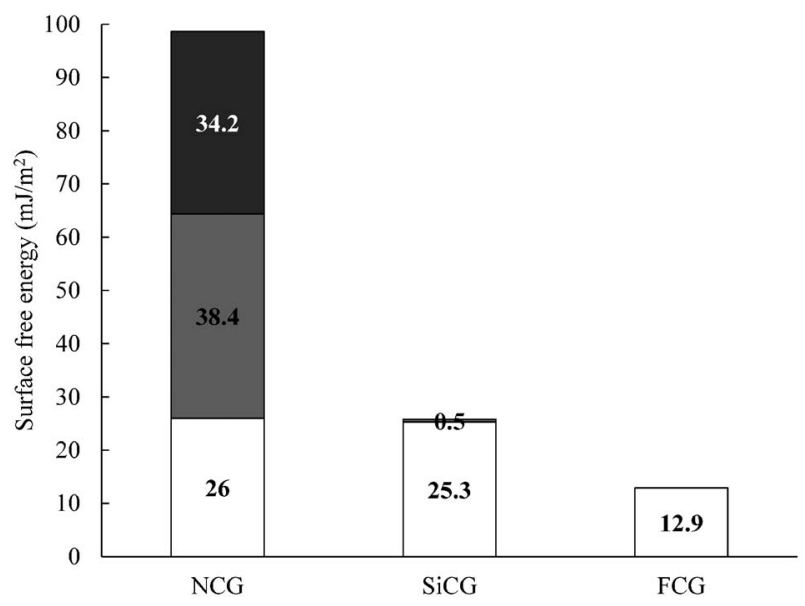

Fig. 5. Surface Free Energy of Each Glass

$\square$, h (hydrogen bond component), $\mathbf{\square}, \mathrm{d}$ (variance component), $\square, \mathrm{p}$ (polar component).

る双極子により分子同士が引き合う力」，双極子成 分は「極性分子が永久双極子により生じた電荷の隔 たりにより正負で向き合って引き合う力」，水素結 合成分は「電気陰性度が大きな原子と水素原子間の 強い極性により，水素原子が他の分子の電子供与性 の高い原子と結びつく, van der Waals 力よりも強 い力」と定義している. ${ }^{13)}$ 各プローブ溶液の接触角 を Table 4 に，北崎・畑らの式 Eqs. (1)，(2)より算 出した各ガラスの表面自由エネルギーを Fig. 5 に 示す。全体的な表面自由エネルギーは NCG（98.6 $\left.\mathrm{mJ} / \mathrm{m}^{2}\right)$, SiCG $\left(25.8 \mathrm{~mJ} / \mathrm{m}^{2}\right)$, FCG $\left(12.9 \mathrm{~mJ} / \mathrm{m}^{2}\right)$ であり，表面コーティングにより $\mathrm{SiCG}$ は $\mathrm{NCG}$ の 約 26\%, FCG は約 12\%の低值を示したことから, コーティングによる表面エネルギーが低下した結 果，接着エネルギーも低下し，非接着性の増加，す なわち，撥水性が向上したものと考えられた。

各成分に着目すると，水素結合成分は NCG にの み認められ, 各シロップ剂で認められた高い残存率 はそれぞれのシロップ剂に含まれる添加剤とガラス 表面との水素結合， van der Waals 力など様々な相 互作用によるものと考えられる。また，SiCGには 


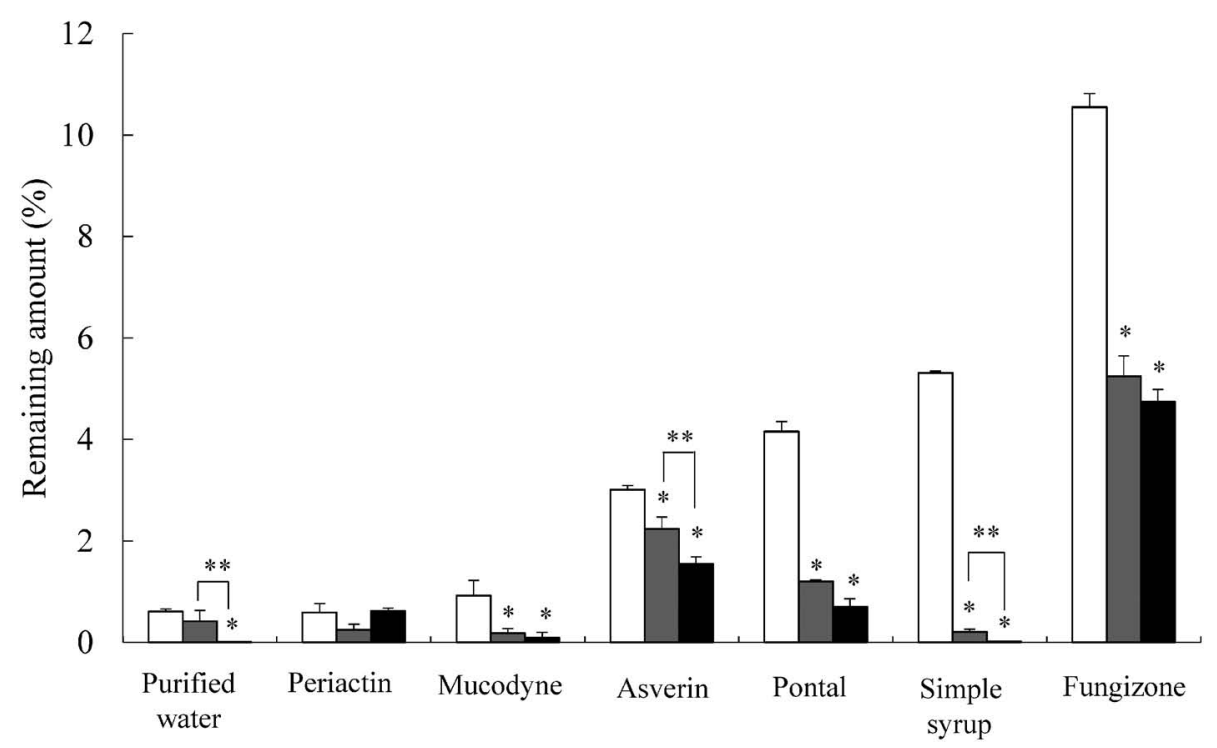

Fig. 6. Remaining Amount of Various Sample Solutions

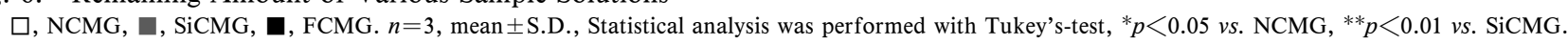

極性成分が $0.5 \mathrm{~mJ} / \mathrm{m}^{2}$ と低值ではあるが認められ た. SiCGへの残存率が FCGよりも高いのは全体 的な表面自由エネルギーが大きいことに加え，双極 子成分の関与も示唆されるが，本実験系で用いた試 料のうちどの成分が影響しているのかは明らかにで きず，今後の課題である.

5. 各メートグラスにおける試料の残存率 各 メートグラスにおける試料の残存率を Fig. 6 に示 す。ペリアクチンシロップを除き， $\mathrm{SiCMG}$ 及び FCMG の試料の残存率は, NCMG と比較して減少 した。 また，添加物を含まない精製水及び単シロッ プの FCMG における試料の残存率は, SiCMG と 比較して有意に減少した（Fig. 6)。このような現 象はメートグラスの表面自由エネルギーだけでな く, 試料の粘性も関連すると考え, 試料の粘度と残 存率との相関について検討したところ，いずれの メートグラスにおいてもシロップの粘度の増加に伴 い，高い残存率を示し，特に NCMG に対する残存 性は粘度の影響を受けることが明らかになった (Fig. 7).

一方，ペリアクチンシロップで認められた現象の ように, SiCMGよりも FCMG の方が高い残存率 を示す場合もあることから，粘性以外の要因も考え られた，その要因の 1 つとして，試料中に含まれる 成分のガラス表面へのぬれ性が関与している可能性 が考えられた。

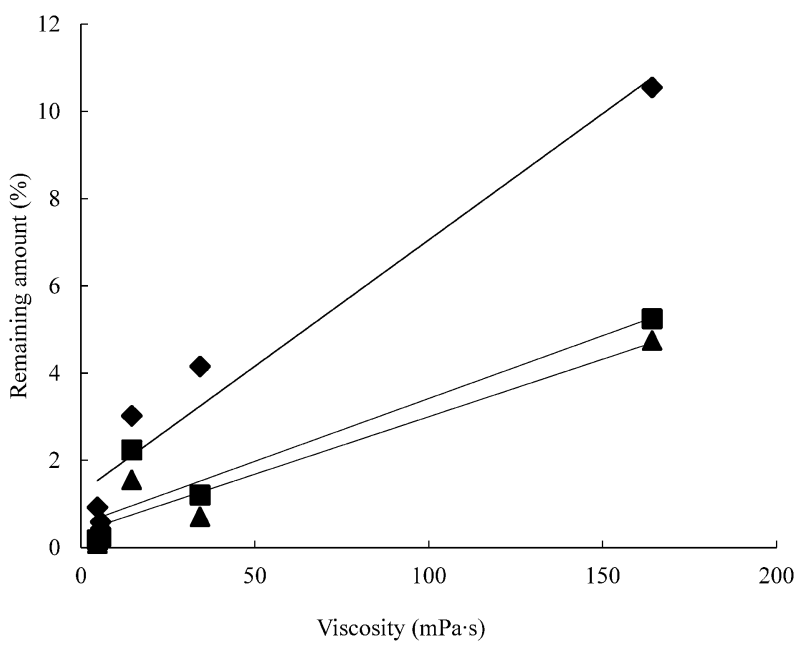

Fig. 7. Relationship between Remaining Amount of Syrups and Viscosity of Various Sample Solutions

$\diamond$, NCMG, $\mathbf{\square}$, SiCMG, $\mathbf{\wedge}$, FCMG.

そこで，本研究で使用したシロップ剂すべてに含 有されている成分ではないが，ぬれ性に影響する成 分としてエタノール及び界面活性剂に着目した。こ れらの残存率に及ぼす影響を検討するため，種々の 混合比率のエタノール・単シロップ混合溶液及び異 なる HLB 值の非イオン界面活性剤水溶液を調製 し, 同様の実験を行った.

5-1. エタノールの表面張力, 接触角及び試料の 残存率への影響 エタノールと単シロップ混合溶 液の表面張力を Table 5 に，接触角を Table 6 に示 
Table 5. Surface Tension of Simple Syrups with or without Various Amount of Ethanol

\begin{tabular}{ccc}
\hline \hline Sample No. & $\begin{array}{c}\text { Simple syrup : EtOH } \\
(\mathrm{mL}: \mathrm{mL})\end{array}$ & $\begin{array}{c}\text { Surface tension } \\
(\text { dyne/cm })^{\mathrm{a}}\end{array}$ \\
\hline S0 & $100: 0$ & 77.9 \\
S1 & $99: 1$ & 42.5 \\
S5 & $95: 5$ & 39.6 \\
S10 & $90: 10$ & 33.1 \\
\hline
\end{tabular}

a Measured at $20 \pm 0.5^{\circ} \mathrm{C}$.

Table 6. Contact Angle of Simple Syrups Containing Various Amount of Ethanol

\begin{tabular}{|c|c|c|c|c|}
\hline $\begin{array}{l}\text { Sample } \\
\text { No. }\end{array}$ & $\begin{array}{l}\text { Simple syrup : EtOH } \\
(\mathrm{mL}: \mathrm{mL})\end{array}$ & $\operatorname{NCG}\left({ }^{\circ}\right)^{a}$ & $\operatorname{SiCG}\left({ }^{\circ}\right)^{\mathrm{a}}$ & $\operatorname{FCG}\left({ }^{\circ}\right)^{a}$ \\
\hline S0 & $100: 0$ & 30.7 & 104.6 & 118.2 \\
\hline $\mathrm{S} 1$ & $99: 1$ & 30 & 105.7 & 115.2 \\
\hline S5 & $95: 5$ & 31 & 101.5 & 110.3 \\
\hline $\mathrm{S} 10$ & $90: 10$ & 16.4 & 81.5 & 94.6 \\
\hline
\end{tabular}

a Measured at $20 \pm 0.5^{\circ} \mathrm{C}$.

す. エタノール含有量の増加に伴い表面張力は低下 した。 また，接触角はエタノールの含有率が 0 から 5\%（S0，S1 及び S5）の系では，いずれのガラス においても 0-7ㄷ, 減少の程度は小さく, ガラス 表面のぬれ性にほとんど影響しないと考えられた。 しかし，エタノールを $10 \%$ 含有する試料（S10）で は，いずれのガラスにおいても接触角は低值を示し たことから，ガラス表面のぬれ性に影響すると考え られた。

Figure 8 に 0 , S1, S5 及び S10 の NCMG， SiCMG 及び FCMG に対する残存率を示す。試料
の残存率は, $\mathrm{SiCMG}, \mathrm{FCMG}$ ともに有意に減少し たが，試料中のエタノール含有量が増加すると残存 率の増加傾向が認められた。一方，コーティングを 施していない NCMG ではエタノールの含量の増加 とともに残存率は低下傾向を示した。黒田らは ニュートン流体の性質を示すシロップ剂において, ガラス器壁への付着量と粘度に関連性があると報告 している. ${ }^{14)}$ また，山本らはシロップの粘度とガラ ス製メートグラス内への薬液残存率の相関性につい て検討し，シロップ斉の粘度が $57 \mathrm{mPa} \cdot \mathrm{s}$ 以上であ るとき，ガラス製メートグラスの付着残存率は 6-7

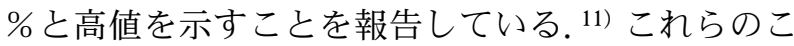
とから本実験系においても，単シロップにエタノー ルを添加することで試料の粘性が低下した結果, NCMG における残存率が減少傾向を示したものと 推察される.

以上のことから，両親媒性物質であるエタノール は，その含有量によりコーティングを施したガラス 表面においてぬれ性に影響することが明らかとなっ た.

5-2. 界面活性剤水溶液の表面張力之試料の残存 率への影響 HLB 值 $11.5 ， 14.5$ 及び 19.0 の POE 水溶液を調製し，各試料の表面張力を測定し た結果, 高い HLB 值の試料は高い表面張力を示し た（Table 7)。また，各界面活性剤水溶液のメート グラスへの残存率を Fig. 9 に示す. NCMG に対す る残存率は HLB 值の増加に伴い, 低值を示した. すなわち，表面張力の大きな HLB 值 19.0 はガラ ス表面に対して濡れ難いため，いずれのメートグラ

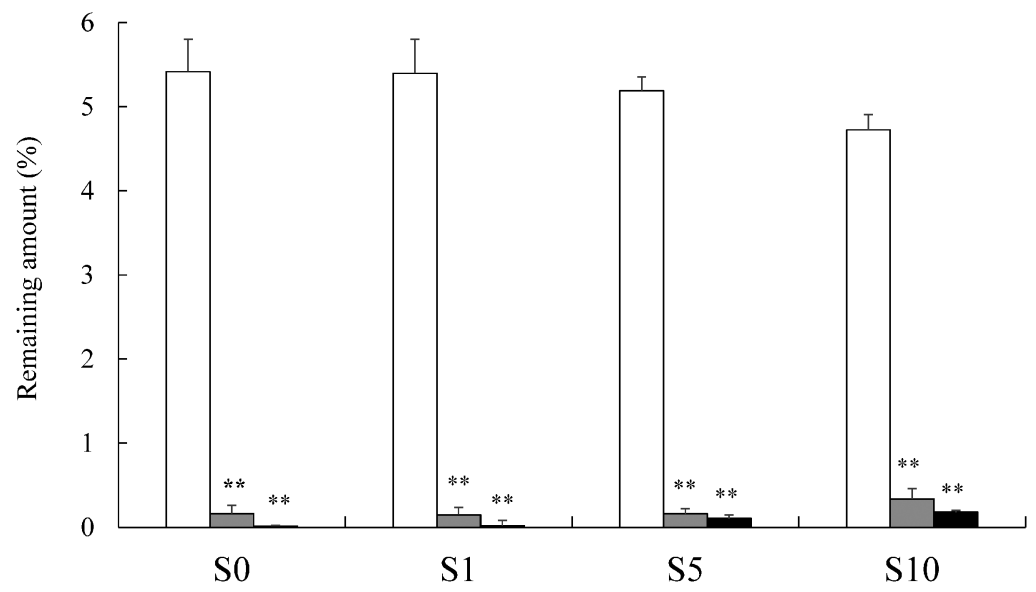

Fig. 8. Remaining Amount of Simple Syrups Containing Various Amount of Ethanol

$\square$, NCMG, $\square$, SiCMG, $\mathbf{\square}$, FCMG. $n=3$, mean \pm S.D., Statistical analysis was performed with Tukey's-test, ${ }^{* *} p<0.01 v s$. NCMG. 
Table 7. Surface Tension of Various 1\% POE Solutions

\begin{tabular}{cc}
\hline \hline HLB value & Surface tension $(\text { dyne } / \mathrm{cm})^{\mathrm{a}}$ \\
\hline 11.5 & 22.6 \\
14.5 & 29.8 \\
19.0 & 40.9 \\
\hline
\end{tabular}

a Measured at $20 \pm 0.5^{\circ} \mathrm{C}$.

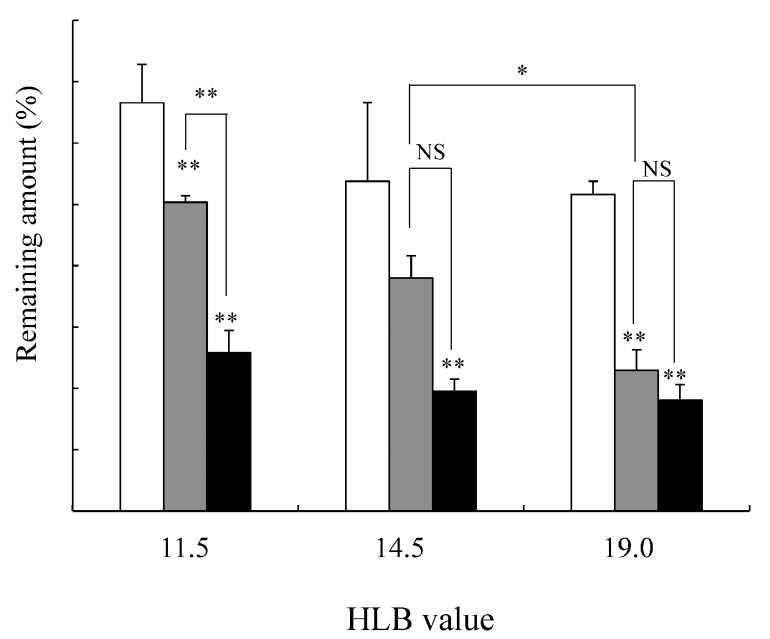

Fig. 9. Effect of HLB on the Adhesion Property of $1 \%$ POE Aqueous Solution to Various Graduated Glasses

$\square$, NCMG, $\square$, SiCMG, $\mathbf{\square}$, FCMG. $n=3$, mean \pm S.D., Statistical analysis was performed with Tukey's-test, ${ }^{*} p<0.05,{ }^{* *} p<0.01$.

スにおいても HLB 值 11.5 及び 14.5 と比較して残 存率は低值を示した。いずれのメートグラスにおい てもシリコーン樹脂及びフッ素樹脂コーティングす ることで，水溶液の残存率は有意に低下した。特 に，表面張力が小さい HLB 值 11.5 の水溶液で は，各メートグラス間で残存率の差が顕著に現れた.

また，材質毎に比較してみると， NCMG 及び FCMG では HLB 值の増加に伴い残存率に低下傾向 が認められたが，これらの值間に有意な差はなかつ た。一方，SiCMG では HLB 值 14.5 と 19.0 におい て有意な差が認められた $(p<0.05)$. SiCG は低值 ではあるものの極性成分を有する（Fig. 5）ことか ら， SiCG 表面を覆うジメチルポリシロキサン中の 極性基と試料溶液との相互作用が推察されたが，分 光学的手法や接触角測定など，これらの推察を支持 するための詳細な検討が今後必要である.

\section{結}

論

本実験系ではモデルデバイスとしてメートグラス を用いたが，ホウケイ酸ガラス製メートグラスに
フッ素樹脂コーティングを施すことにより表面自由 エネルギーを低下させることで，通常のメートグラ スと比較し，メートグラスへの試料の残存性を低減 できることが明らかとなった。また，フッ素樹脂 コーティング処理ガラスはシリコーン樹脂コーティ ング処理ガラスと同等若しくは同等以上の撥水機能 を有した。特に粘性の高いファンギゾンシロップ, ポンタールシロップ及びアスベリンシロップにおい ては，シリコーン樹脂コーティングよりも有意に高 い撥水効果を示した。これらのことから，ガラス表 面と医薬品の水素結合による相互作用はなく，ガラ ス器具やガラスバイアルへの医薬品の吸着を始めと する相互作用を最小限に抑えられることが示唆され た。しかし，シロップ剂の粘性が残存率に影響する ことから，コーティング処理したメートグラスでも 傾倒角度及び流下時間などへの土夫が必要と考える.

本研究で行ったホウケイ酸ガラス表面のフッ素樹 脂コーティング処理は，ガラスバイアルだけではな $<，$ 輸液調製に用いられる $70 \%$ ブドウ糖注射液や 院内製剂にて気管支造影剤の希釈に用いられるカル ボキシメチルセルロースナトリウムのような高粘度 溶液を計量・保存するためのガラス製メスシリン ダーや高圧蒸気滅菌耐性用ビンなど，多様なガラス 製器具に応用可能であり, 調剤性の向上にも寄与で きると考える。

謝辞本研究に際しまして実験にご協力頂きま した荒俣章文氏に深謝の意を表します。また，種々 のポリオキシエチレンラウリルエーテルをご提供頂 きました，日光ケミカルズ株式会社に感謝の意を表 します.

利益相反 河野弥生（株式会社ナミコスから コーティングプレパラート及びコーティングメート グラスの供与, 日光ケミカルズ株式会社からポリオ キシエチレンラウリルエーテルの供与)，大津早紀 (開示すべき利益相反はない)，馬場孝夫（株式会社 ナミコスの社員)，花輪剛久（株式会社ナミコスか らコーティングプレパラート及びコーティングメー トグラスの供与). 


\section{REFERENCES}

1) Nakajima S., Kawano K., Nakazawa K., Terada K., Jpn. J. Hosp. Pharm., 14, 335-338 (1988).

2) Kawano K., Matsunaga A., Nakajima S., Jpn. J. Hosp. Pharm., 19, 29-33 (1993).

3) Kawano K., Matsunaga A., Takamatsu S., Nakajima S., Jpn. J. Hosp. Pharm., 20, 537541 (1994).

4) Muramatsu E., Hanawa T., Suzuki M., Tanaka M., Kawano K., Nakajima S., Jpn. J. Hosp. Pharm., 26, 471-477 (2000) .

5) Yano R., Nakamura T., Aono H., Wakiya Y., Masada M., Yakugaku Zasshi, 121, 139-144 (2001).

6) Mathes J., Friess W., Eur. J. Pharm. Biopharm., 78, 239-247 (2011).

7) Höger K., Mathes J., Frieß W., J. Pharm.
Sci., 104, 34-43 (2015).

8) Hormes R., PDA Journal of GMP and Validation in Japan, 7, 16-20 (2005).

9) Bamba T., Aramata M., Kishimoto J., WO2013179514 A1 (2013).

10) Pharmaceuticals and Medical Devices Agency, Glass containers: 〈https://www.pmda.go.jp/ files/000213851.pdf $\rangle$, cited 6 June, 2017.

11) Yamamoto Y., Suzuki T., Fukami T., Kamano M., Tomono K., Jpn. J. Pharm. Health Care Sci., 34, 691-698 (2008).

12) Yamamoto Y., Suzuki T., Hashizaki K., Ogura M., Umeda Y., Hidaka S., Fukami T., Tomono K., Yakugaku Zasshi, 130, 10851091 (2010).

13) Kitazaki Y., Hata T., J. Adhesion, 4, 123-132 (1972).

14) Kuroda M, Hirota S., Yakuzaigaku, 37, 152158 (1977). 